\title{
The Financing of Wastewater Treatment and the Balance of Payments for Water Services: Evidence from Municipalities in the Region of Valencia
}

\author{
Marcos García-López *(D), Joaquín Melgarejo (D) and Borja Montano (D) \\ University Institute of Water and Environmental Sciences, University of Alicante, \\ 03690 San Vicente del Raspeig, Spain; jmelgar@ua.es (J.M.); borja.montano@ua.es (B.M.) \\ * Correspondence: marcos.garcialopez@ua.es
}

Citation: García-López, M.; Melgarejo, J.; Montano, B. The Financing of Wastewater Treatment and the Balance of Payments for Water Services: Evidence from Municipalities in the Region of Valencia. Sustainability 2021, 13, 5874. https://doi.org/10.3390/su13115874

Academic Editor: Charikleia Prochaska

Received: 19 April 2021

Accepted: 20 May 2021

Published: 24 May 2021

Publisher's Note: MDPI stays neutral with regard to jurisdictional claims in published maps and institutional affiliations.

Copyright: (C) 2021 by the authors. Licensee MDPI, Basel, Switzerland. This article is an open access article distributed under the terms and conditions of the Creative Commons Attribution (CC BY) license (https:// creativecommons.org/licenses/by/ $4.0 /)$.

\begin{abstract}
Pollution from wastewater discharges requires the treatment of all wastewater to maintain water bodies in good condition, as well as the possibility of reusing this water. Thus, wastewater treatment is an activity that has developed significantly in the Region of Valencia and has significant costs, including energy, which represents the main economic cost and an important environmental cost. In this way, efficiency and adequate financing of this activity are essential to minimise our environmental impact. However, the main funding tool currently does not allow us to address this issue, so we have a wastewater treatment with a high environmental cost in the form of greenhouse gas emissions. This tool is part of the revenues of water services, so it is not entirely independent, but it also seeks to prevent households from paying too high a total price. This leads to a situation where changes are needed to improve the financing of the different water services, as the financial resources obtained are insufficient and do not allow the current environmental problems to be solved. The analysis shows the importance of an appropriate tariff structure, as well as the need to include aspects such as water pollution and energy costs in the wastewater treatment tariff.
\end{abstract}

Keywords: water prices; water tariffs; sanitation taxes; wastewater treatment costs; energy costs; household budgets

\section{Introduction}

Water resources are fundamental to all human activity, so their efficient management is essential to achieve the environmental sustainability of society. Unfortunately, water is a scarce resource in some parts of the world, and expectations for the future are for a reduction of annual rainfall, increased periods of resource scarcity and increased incidence of extreme weather events [1]. It is therefore essential to maximise efficiency in the management of an essential resource whose situation is expected to worsen. This is the situation in the Mediterranean area, a region where droughts or periods of scarcity, through their economic, social and environmental impacts, are a major problem [2,3]. Droughts, compared to other phenomena such as floods or storms, are more difficult to detect and quantify, which, together with the prospect of increasing global temperatures, brings with it the need to optimise our use of water resources [3].

In this context, one of the most important activities is wastewater treatment and reuse, which has developed significantly in the Region of Valencia (Spain) as a response to the scarcity of resources [4]. Purification is compulsory according to European regulations, as it is of great importance to reduce pollution from discharges in order to maintain water bodies in good condition [5]. Thus, there are minimum water quality criteria that must be met in order for the discharge to be considered adequate [6]. Moreover, pollution reduction is not the only contribution of this activity, as through improved treatment it is possible to reuse reclaimed water, thus generating additional water resources and relieving pressure on water bodies [7]. On the other hand, however, the activity has negative aspects, 
mainly derived from the environmental impact of the activity. This arises from various factors such as the construction of facilities or the use of chemical products, but the high energy consumption required to carry out the activity stands out $[8,9]$. This energy cost, in addition to the pollution generated, as it comes largely from fossil fuels [4], is the main economic cost of the activity, so maximising the energy efficiency of this activity has both economic and environmental benefits [10]. In any case, wastewater treatment partially avoids the deterioration of the quality of water bodies by reducing the presence of pollutants in discharged waters, so it is not an activity that should be abandoned. In this sense, it is expected that, in the future, if the status of these bodies of water continues to deteriorate, the costs of wastewater treatment will increase, as the pollution to be removed from the wastewater will be greater [11]. Finally, it should be borne in mind that the choice of treatment is linked to energy consumption and economic cost [12]. Moreover, these differences are not constant; the cost can vary significantly depending on the size of the installation [13], as well as many other aspects [14].

This activity, of course, requires sufficient funding to be developed, and, as the Water Framework Directive [5] indicates, it is the pollutant's responsibility to pay for correcting it. In this case, it is the water consumer who must pay for treatment, as it is his or her water consumption that causes the need for treatment. Thus, in the Region of Valencia, financing is obtained through a tax, called the sanitation tax, which is levied on domestic and industrial water consumption. Therefore, this tax is mainly responsible for the treatment aimed at reducing pollution from discharges, as the treatments aimed at regenerating wastewater for reuse are usually financed by the end user of the water. In this region, the levy is applied at the same time as local tariffs, so some water price effects can be attributed to it. Of course, the main one is the cost recovery of the activity, which is essential, since, between investment, operational and maintenance costs, the costs are significant and the good condition and functioning of the infrastructure must be pursued [15]. Full cost recovery is very difficult to achieve due to the high energy consumption, but even so, it is necessary to raise the amount needed to maintain the activity $[16,17]$. The next price effect is to reduce consumption, since water is a normal good, and if its price increases, its consumption should decrease [18]. However, we must never forget that there is a basic consumption that cannot be reduced by price increases [19]. In addition, it may be found that the tariff does not adequately convey the cost of the service or the scarcity of water, such that the relatively small amount of the water invoice would not change consumption. This issue has two aspects of interest: firstly, the difficulty of predicting consumer response, with its respective influence on public revenues, and secondly, the need for additional measures, such as awareness-raising campaigns, to change the behaviour of water users [20]. There are many other effects of water pricing policy, but the design of water pricing policy depends largely on the economic, environmental, social and political situation [18]. In order to face these characteristics, water prices have a certain capacity to adapt. In this sense, the water tariff can take into account some specific aspects such as scarcity at the time of consumption [21], the time of year of consumption [22] or the number of household members [23], although additional information is missing when designing the tariff [23]. Among these factors, the household structure is of particular importance, because if prices are set without taking into account the number of household members, household budgets may be affected differently on the basis of this characteristic [24]. In other words, the tariff should aim for fairness and not overly affect household finances $[25,26]$, although it may be the case that the water invoice is very low for the household [26].

All these details are relevant when designing the price of a water service, the financing of which enables water policy to be improved [17]. Currently, the sanitation tax in the Region of Valencia does not have consumption brackets but has a fixed service fee and a variable fee that is applied equally regardless of how much has been consumed. The feature it includes is that, depending on the size of the municipality, both components of the tax vary, so that smaller municipalities pay a lower amount than larger ones. Given the current situation of high energy consumption, with its respective environmental cost, the aim of this 
work is to analyse, with recent data, the energy consumption of the wastewater treatment plants in the Region of Valencia, as well as the situation of the sanitation tax. In this way, the aim is to provide knowledge with a view to its modification, which would make it possible to reduce the considerable environmental impact of an activity that we cannot do without. However, this work analyses a specific tariff structure, so without additional information, it may not be useful for other regions with different tariffs and environmental, social and economic situations. For this reason, when analysing the information available for the Region of Valencia, the tariff structure of other places will also be assessed, thus establishing the usefulness of the article for obtaining water revenues in an efficient way in other regions. With this objective in mind, the next section will explain the data used and the methodology followed. Then, the results will be commented on and discussed, and finally, the conclusions obtained will be provided.

\section{Materials and Methods}

In order to meet the proposed objective, a series of data from various sources is used to address the issue in a more complete way than with only specific data. Moreover, these data have been worked on in a specific way to address the current problem.

\subsection{Materials}

In terms of data, several sources have been used to carry out this work (see Supplementary Materials). Firstly, basic information on the wastewater treatment plants in the Region of Valencia is available from the EPSAR (Entidad Pública de Saneamiento de Aguas Residuales) website. Specifically, the analysis uses the average energy consumption $\left(\mathrm{kWh} / \mathrm{m}^{3}\right)$, the population served (population equivalent), the quantity of wastewater treated $\left(\mathrm{m}^{3} /\right.$ day), the quantity of wastewater originally designed to be treated in the plant (capacity of treatment plant measured as $\mathrm{m}^{3}$ /day) and the removal efficiencies in terms of Suspended Solids (SS), Biological Oxygen Demand (BOD) and Chemical Oxygen Demand (COD). The quantity of wastewater originally designed to be treated in the plant is constant, but the rest of the variables are 2018-year data obtained for each plant individually. Finally, it should be noted that these data are the official operating results of the facilities in the Region of Valencia. However, we do not go into detail on the treatments used on each plant because there are big differences between them, the treatments are diverse and therefore it is very difficult to find a general pattern.

On the other hand, information is included from the Household Budget Survey, which is elaborated annually by the National Statistics Institute (INE for its Spanish acronym). Four different editions of the survey are used, controlling by year, with the aim of increasing the available sample. Specifically, information is available for the years 2016, 2017, 2018 and 2019. This survey works on Spanish households budgets, so it is not specific to water resources, but it allows to include data on the price paid for water (EUR/year or EUR $/ \mathrm{m}^{3}$ ) or for sanitation services (EUR / year or $€ / \mathrm{m}^{3}$ ), the number of household members, household income (EUR/year) and water consumption ( $\mathrm{m}^{3} /$ year). In addition, due to the differences in sanitation charges depending on the size of the municipality, the latter variable is also be included in the analysis. In order to eliminate cases that are very far from the average, which would distort it, several criteria have been followed. Firstly, households with an annual income of more than EUR 180,000 or an invoice of more than $25 \%$ of income have been eliminated. Households with a unit price of more than EUR 6, an annual invoice of more than EUR 1000 or an annual invoice per person of more than EUR 400 have also been eliminated. Finally, in terms of consumption, households with an annual consumption of more than $1000 \mathrm{~m}^{3}$ or with an annual consumption per person of more than $400 \mathrm{~m}^{3}$ have been eliminated. Unfortunately, households are not linked to any particular city, as this is part of ensuring the anonymity of the survey respondents, so it is not possible to take into account the particular characteristics of each city such as the number of households in the city or supply water pricing system. 
To these two main sources of information were added the tariff for the sanitation canon of the Region of Valencia (from the management report of EPSAR [4]) and the current tariff for water supply of the city of Alicante (from the website of Aguas de Alicante), which were a city of this region and allow us to observe differences in the way revenues are obtained. Information is also included on the cost recovery of the hydrographic confederations present in the Region of Valencia, such as those of the Júcar and Segura.

\subsection{Methods}

With the above-mentioned data, the analysis is carried out in two distinct parts. Firstly, the available data on the wastewater treatment plants will be used in order to show some aspects of interest. This will be done through maps created with the GeoDa program, thus taking advantage of the geographical location of the facilities in the region. The data are not represented on a map as such, but, due to the use of coordinates, the figures included have the same shape as the Region of Valencia. After this, the wastewater treatment plants are divided into different groups through a cluster analysis. Specifically, this analysis is carried out on the basis of all the variables from the previous section. However, in order not to give too much importance to the removal efficiencies, what is included is the average of the 3. Thus, the classification is done by 4 variables: the average energy consumption, the quantity of wastewater treated, the proportion of the project flow used and the average removal efficiency. The number of clusters has been set to 5, the case grouping method used is K-means and the measure of association used is the Euclidean distance.

Regarding the data on households, tariffs and cost recovery of the hydrographic confederations, the main tool will consist of commenting on basic data. Thus, a table will be shown with data on households from the Household Budget Survey. This table will contain the different variables of interest depending on the size of the municipality in order to make comparisons with the structure of the sanitation tax. As for the tariffs and cost recovery data, these will be shown in tables before the data per household to contextualise the situation.

\section{Results}

Based on the above data and methods, it is possible to pursue the proposed objective. Thus, this section shows the results obtained, which allow us to generate discussion and draw certain conclusions.

\subsection{Energy Consumption of Wastewater Treatment Plants}

The aspect of wastewater treatment that we would like to highlight is its high energy consumption, which, as mentioned above, is associated with significant economic costs and greenhouse gas emissions. In other words, improving the energy efficiency of this activity and replacing its energy consumption based on fossil fuels with consumption from renewable sources are key aspects. In this sense, the first point is to show the energy consumption of the wastewater treatment plants in the Region of Valencia, which is done by means of Figure 1. This map shows the flow treated per year (size of the circle) and the average energy consumption (colour of the circle). As can be seen, the larger plants have a low energy consumption, but these are not very numerous, as there is a large number of small installations. Thus, a large dispersion can be observed between plants of similar size, with the northern part of the region not having a particularly high average energy consumption despite the high number of small plants. In the central part, although there is a greater number of plants with high consumption, there is also a large number with low consumption. However, the situation in the southern part of the region is very different, as the proportion of plants with high consumption is higher than in the other two parts of this region. In other words, it is possible that there is some important difference that conditions the activity in this region. 

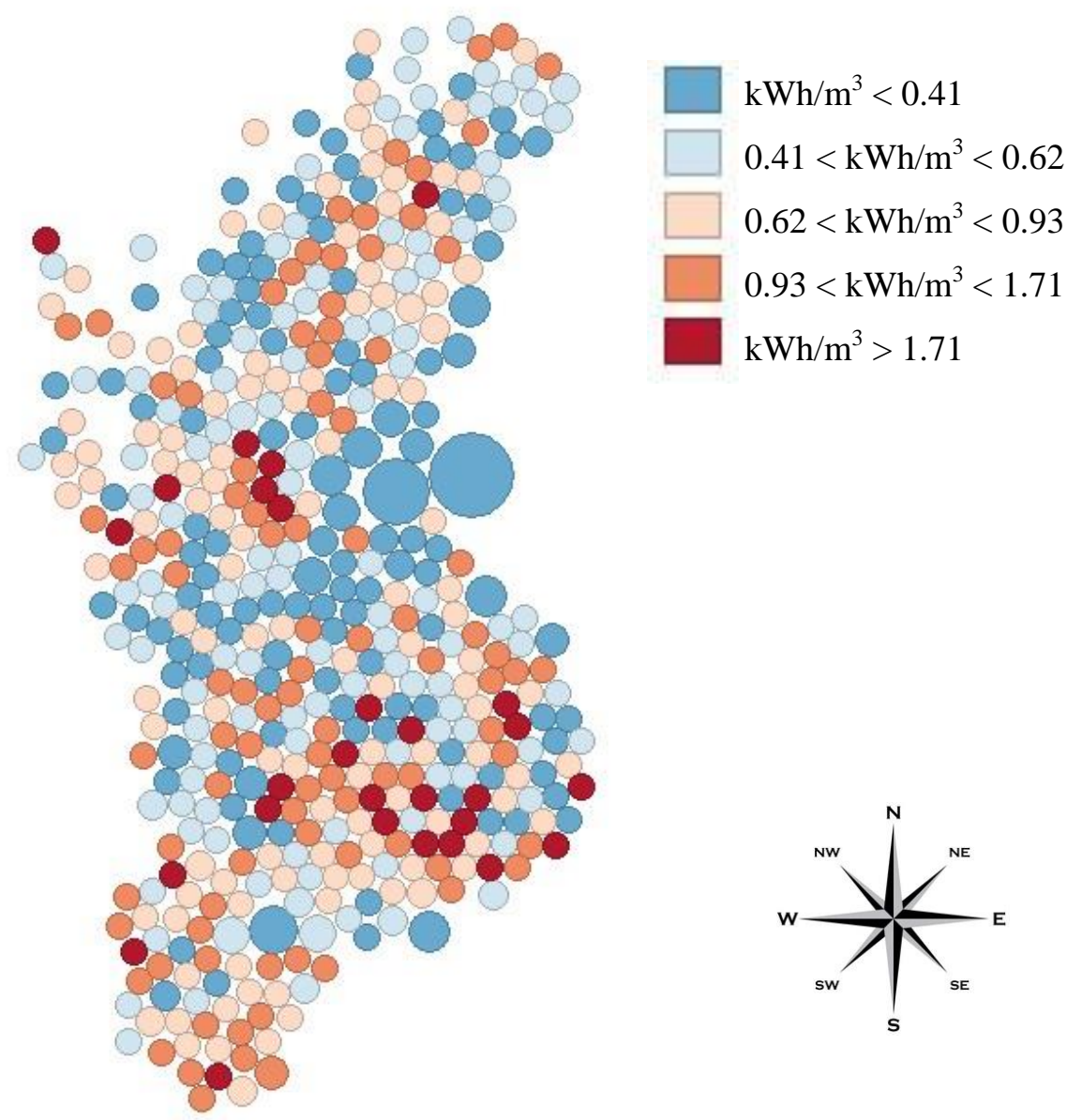

Figure 1. Map of wastewater treatment plants in the Region of Valencia, with the size of the circles indicating the amount of wastewater treated and the colour indicating energy consumption. Source: own elaboration based on EPSAR data.

For more information about the plants, Figure 2 shows the population served (size of the circle) and the proportion of the project flow utilised (colour of the circle). On this occasion, what we can see is how, in general, the installed capacity is not being utilised. In this sense, the utilisation of the installation cannot be forced, and it could be the case that certain plants are designed to be able to withstand the flow of wastewater at the time of peak consumption. For this reason, in annual terms, these plants may appear to be underutilised, as for a large part of the year the installation does not receive a large amount of wastewater. However, even in this case, there are a significant number of plants with very low-capacity utilisation, such that more treatment capacity is available than necessary. Moreover, this wasted capacity is concentrated in smaller plants, especially in the northern part of the region.

Finally, Figure 3, in order to provide information about the removal efficiencies, shows the amount of wastewater treated (size of the circle) and the average removal efficiencies (colour of the circle). Thus, we can see a clear relationship between size and yields, with larger plants having higher yields. In fact, among the small plants, there are some that do not meet the criteria set out in the regulation [6]. These are small installations that have a low impact associated with them, but even so, they have an impact that is not adequately addressed. In addition, most of the plants with low disposal yields are concentrated in the northern and central parts of the region. This fits with the previous result of higher energy consumption in the southern part of the region. In other words, the southern facilities have higher energy costs in exchange for improved disposal efficiencies and therefore less pollution from discharges and easier wastewater reuse. 


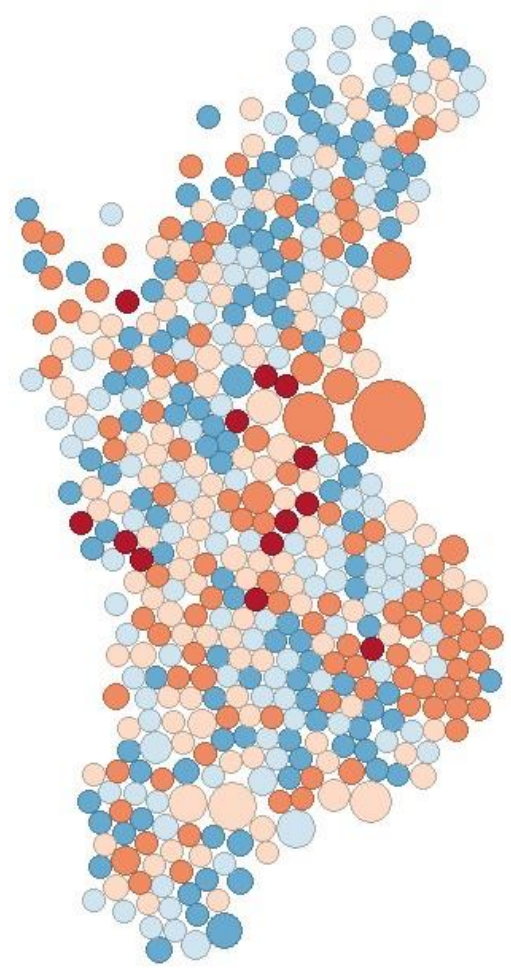

$\%<0.356$

$0.356<\%<0.502$

$0.502<\%<0.703$

$0.703<\%<1.223$

$\%>1.223$

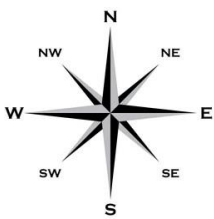

Figure 2. Map of wastewater treatment plants in the Region of Valencia, with the size of the circles indicating the population served and the colour indicating the percentage of installed capacity utilisation. Source: own elaboration based on EPSAR data.

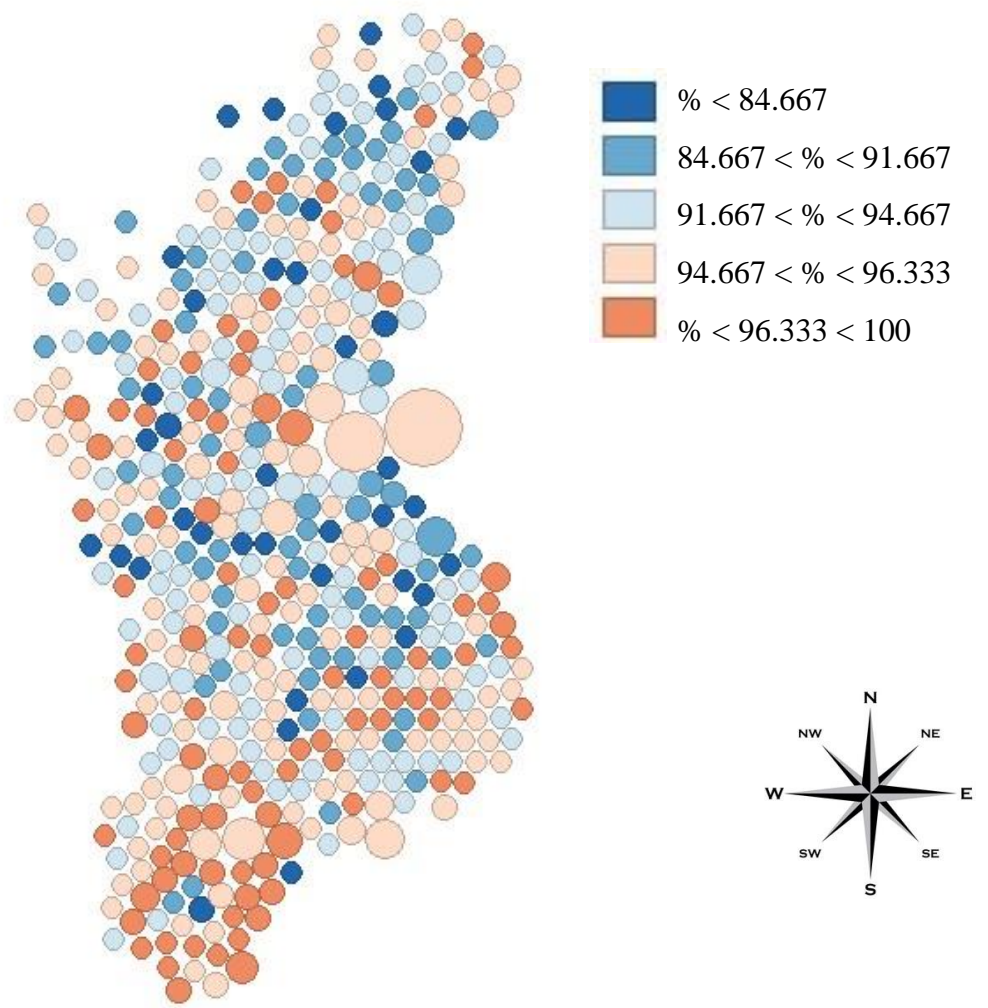

Figure 3. Map of wastewater treatment plants in the Region of Valencia, where the size of the circles indicates the amount of wastewater treated and the colour indicates the percentage of disposal performance (measured as the average of SS, BOD and COD). Source: own elaboration based on EPSAR data. 
On the other hand, in order to expand the information about the wastewater treatment plants in the region, they have been grouped by means of a cluster analysis, whose results are shown in Table 1 . The grouping and basic data of the five clusters created are in line with the information obtained from Figures $1-3$, as the grouping is closely related to the size of the facilities. Thus, the first group contains 428 plants, representing $88.61 \%$ of the total, which, added to the 38 plants in the second group, makes a total of $96.48 \%$. From here on, the groups are made up of plants of increasing size, until the last group is made up of one plant that is significantly larger than all the others. It can also be seen that the plants in the group have the lowest project flow utilisation, the worst disposal performance and the highest energy consumption of all. Of course, within this group, there is significant heterogeneity, which could be observed thanks to the maps. In any case, it is worth noting that there is a large number of small plants that are very difficult to operate efficiently, which has led in the past to proposals to concentrate flows as much as possible to reduce the use of small plants [9].

Table 1. Basic data on the groups of treatment plants in the Region of Valencia.

\begin{tabular}{|c|c|c|c|c|c|}
\hline Variable/Cluster & 1 & 2 & 3 & 4 & 5 \\
\hline Population served (Inhabitant equivalents) & 1889.89 & $36,618.50$ & $125,616.00$ & $308,637.67$ & $852,799.00$ \\
\hline Proportion of project flow used (\%) & 0.55 & 0.58 & 0.63 & 0.73 & 1.06 \\
\hline Energy consumption (kWh $/ \mathrm{m}^{3} /$ year) & 0.80 & 0.58 & 0.43 & 0.28 & 0.23 \\
\hline Wastewater treated $\left(\mathrm{m}^{3} /\right.$ year $)$ & $165,664.23$ & $2,816,987.8$ & $8,748,412.5$ & $24,576,903$ & $77,346,001$ \\
\hline SS removal efficiency (\%) & 91.32 & 95.97 & 95.77 & 95 & 97 \\
\hline BOD removal efficiency (\%) & 94.64 & 96.53 & 97.46 & 97.67 & 98 \\
\hline COD removal efficiency (\%) & 90.01 & 92.97 & 93 & 93 & 94 \\
\hline Removal efficiencies (Mean SS, BOD and COD, \%) & 91.99 & 95.16 & 95.41 & 95.22 & 96.33 \\
\hline Number of plants & 428.00 & 38.00 & 13.00 & 3.00 & 1.00 \\
\hline Percentage of total plants & 88.61 & 7.87 & 2.69 & 0.62 & 0.21 \\
\hline Cumulative percentage & 88.61 & 96.48 & 99.17 & 99.79 & 100.00 \\
\hline
\end{tabular}

Source: own elaboration based on EPSAR data.

\subsection{The Situation of Households and Water Supply and Treatment Tariffs}

Given the current situation of the wastewater treatment plants in the Region of Valencia, where high energy consumption represents a significant economic and environmental cost, we now analyse the financial situation of wastewater treatment and reuse. Firstly, Table $2[27,28]$ and Table $3[29,30]$ come from the hydrological plans of the hydrographic confederations of the Júcar and Segura, both of which are present in the Region of Valencia, and show the cost recovery of both confederations. In general terms, cost recovery is low and limits the capacity to act. In terms of reuse, in one case, cost recovery is directly non-existent, while in the other case, there is some recovery, although it is quite low. For collection and treatment in public networks, the share of adequately financed costs is much higher, although there is still a significant lack of funding. Finally, in terms of total costs, we can see that an improvement in cost recovery is expected for the next hydrological cycle, but even with this improvement, the funds available are very limited, which greatly limits the capacity of the basin organisations to introduce modifications if they do not receive greater funding.

Table 2. Cost recovery for reuse, collection and treatment in public networks and total cost recovery of the Júcar Hydrographic Confederation for the hydrological cycles 2015-2021 and 2021-2027.

\begin{tabular}{|c|c|c|c|c|c|}
\hline \multirow[t]{2}{*}{ Cost Recovery } & \multirow[b]{2}{*}{ Júcar Hydrographic Confederation } & \multicolumn{2}{|c|}{ Financial Costs } & \multicolumn{2}{|c|}{ Total Costs } \\
\hline & & 2015-2021 & 2021-2027 & 2015-2021 & 2021-2027 \\
\hline \multirow{3}{*}{ Reuse } & Urban (garden irrigation) & - & - & - & - \\
\hline & Agriculture/ranching & $0 \%$ & $0 \%$ & $0 \%$ & $0 \%$ \\
\hline & Industry (golf)/energy & $0 \%$ & $0 \%$ & $0 \%$ & $0 \%$ \\
\hline \multirow{3}{*}{ Collection and treatment in public networks } & Urban supply & $83 \%$ & - & $75 \%$ & $83.40 \%$ * \\
\hline & Industry/energy & $83 \%$ & - & $75 \%$ & $79.81 \%$ * \\
\hline & Confederation Totals (Including all water services) & $84 \%$ & $93 \%$ & $78 \%$ & $87 \%$ \\
\hline
\end{tabular}

* These data include the economic and environmental costs, but not the resource cost. Source: CHJ, 2015, and CHJ, 2019. 
Table 3. Cost recovery for reuse, collection and treatment in public networks and total cost recovery of the Segura Hydrographic Confederation for the hydrological cycles 2015-2021 and 2021-2027.

\begin{tabular}{|c|c|c|c|c|c|}
\hline \multirow[t]{2}{*}{ Cost Recovery } & \multirow[b]{2}{*}{ Segura Hydrographic Confederation } & \multicolumn{2}{|c|}{ Financial Costs } & \multicolumn{2}{|c|}{ Total Costs } \\
\hline & & 2015-2021 & 2021-2027 & 2015-2021 & 2021-2027 \\
\hline \multirow{3}{*}{ Reuse } & Urban (garden irrigation) & - & - & - & - \\
\hline & Agriculture/ranching & $5 \%$ & $4 \%$ & $3 \%$ & $2 \%$ \\
\hline & Industry (golf)/energy & $53 \%$ & $53 \%$ & $53 \%$ & $53 \%$ \\
\hline \multirow{3}{*}{ Collection and treatment in public networks } & Urban supply & $80 \%$ & $70 \%$ & $46 \%$ & $42 \%$ \\
\hline & Industry/energy & $82 \%$ & $70 \%$ & $47 \%$ & $42 \%$ \\
\hline & Confederation Totals (Including all water services) & $83 \%$ & $82 \%$ & $57 \%$ & $63 \%$ \\
\hline
\end{tabular}

Source: CHS, 2015, and CHS, 2020.

Therefore, the possibility to introduce modifications will be left to EPSAR, the public entity responsible for wastewater treatment and reuse and therefore also responsible for raising the necessary revenues. As mentioned above, the tax establishes a price according to the size of the municipality, as shown in Table 4 [4]. As can be seen, municipalities pay a significantly lower price compared to large municipalities (EUR 0.321 to EUR 0.441). This is related to the fact that the pollution load of wastewater from smaller municipalities is lower than in larger municipalities. However, considering that larger plants are more efficient in terms of energy consumption and disposal performance as well as economic costs, this is a striking fact. In addition, the economic characteristics of each municipality (or size of municipality) should also be considered in order to develop an efficient charge. These characteristics are assessed later, as we now compare the sanitation tax with one of the water supply tariffs. In particular, Table 5 [31] shows the tariff for the city of Alicante, the second-largest city in the Region of Valencia, which has a very particular design. Specifically, this progressive tariff presents an initial consumption bracket at a very low price so that the basic supply is guaranteed at a price that any household can afford. However, as household consumption increases, so does the price, reaching a maximum of EUR $2.85 / \mathrm{m}^{3}$, which is a relatively high price that is, in fact, several times more than the sanitation charge applied to them (EUR 0.441). Although reaching this consumption bracket requires the consumption of a large amount of water, the previous brackets are also expensive at around EUR $2 / \mathrm{m}^{3}$. On the other hand, this tariff has other special features, such as the fact that the service fee has discounts for the long-term unemployed or that the consumption brackets are modified according to the number of household members. Thus, the standard tariff shown in Table 5 only applies to normal households, i.e., not large families. In the case of large families, depending on the number of children, the brackets are modified so as not to overly penalise the consumption of such large households. Therefore, this tariff has a structure that allows for some customisation of the way revenues from the water supply service are obtained.

Table 4. Sanitation tax of the Region of Valencia.

\begin{tabular}{|c|c|c|}
\hline \multirow[b]{2}{*}{ Population Brackets of Municipalities } & \multicolumn{2}{|c|}{ Sanitation Tax } \\
\hline & Consumption Quota (EUR/m³) & Service Fee ( $€ /$ year) \\
\hline $500-3000$ & 0.321 & 32.43 \\
\hline $3001-10,000$ & 0.376 & 39.75 \\
\hline $10,001-50,000$ & 0.412 & 43.81 \\
\hline More than 50,000 & 0.441 & 44.83 \\
\hline
\end{tabular}


Table 5. Standard rate for domestic water consumption in the city of Alicante.

\begin{tabular}{cc}
\hline Household Customers * & Euros $/ \mathrm{m}^{3}$ \\
\hline From 0 to $12 \mathrm{~m}^{3}$ per quarter & 0.01 \\
From 13 to $30 \mathrm{~m}^{3}$ per quarter & 0.7 \\
From 31 to $45 \mathrm{~m}^{3}$ per quarter & 1.95 \\
From 46 to $60 \mathrm{~m}^{3}$ per quarter & 2.02 \\
From $61 \mathrm{~m}^{3}$ per quarter onwards & 2.85 \\
\hline
\end{tabular}

* The service fee depends on the meter. There are some discounts, for example, in the fixed payment for being long-term unemployed or in the variable payment for being a large family (large family being understood as families with 3, 4,5 or 6 or more members, with each of these having sections adapted to the number of members). Source: Aguas de Alicante, 2021.

Finally, as mentioned above, it is essential to know the characteristics of households in a region in order to properly assess a tariff or charge that will be applied to all of them. With this objective in mind, Table 6 shows the available data on households in the Region of Valencia by size of municipality. The values of the variables correspond to the average of all households. Firstly, if we talk about prices, we show the unit price per water tariff, per sanitation service and the total. The first of these prices does not show a clear pattern, but the payment for sanitation is higher in small municipalities. However, these payments present other sanitation services such as sewerage, so they do not accurately reflect the sanitation fee. It should be recalled that the fee is lower in smaller municipalities, so in reality, the fee payment is actually small compared to the total price. In this respect, the total price is between EUR 2.26 and EUR 2.80, of which only a maximum of EUR 0.441 (plus the service fee, which is independent of the amount) corresponds to the sanitation charge. If we take into account consumption per household and per person, we find that both consumptions are lower in the smaller municipalities, so that the higher unit price they present does not correspond to irresponsible consumption, at least in comparison with the rest of the households. If we also include household income in the analysis, we find that household income is high in small municipalities; in fact, income per person is the highest of all. Households in municipalities with between 50,000 and 100,000 inhabitants have a higher income per household, but their higher number of household members means that the income per person is lower than in smaller municipalities. Households of all other sizes have a lower income than the households discussed above. Finally, the key aspect of this analysis is the share of water and sanitation payments in total household income. Thus, since water supply is more expensive, it has a higher share of income than sanitation services. In total terms, this proportion is around $1.5 \%$ for households in municipalities with less than 50,000 inhabitants and around $1.3 \%$ for the rest. That is to say, if we value the price of water and sanitation payments together, we find that, in relative terms, households in small municipalities suffer a higher cost. However, this is not due to the sanitation charge, as this is lower in precisely these types of municipalities. In other words, in relative terms, smaller municipalities have a higher water supply price but a lower sanitation charge compared to larger municipalities. Therefore, as can be deduced, the situation is complex, and introducing modifications can be very complicated, but it is necessary given the current situation of scarce resources, high pollution and inefficiency in the wastewater treatment plants of the Valencian Community. 
Table 6. Characteristics of households in the Region of Valencia by size of municipality.

\begin{tabular}{|c|c|c|c|c|c|}
\hline Size of Municipality (Inhabitants) & \multirow{2}{*}{$\begin{array}{c}\text { Less Than } \\
10,000\end{array}$} & \multirow{2}{*}{$\begin{array}{c}\text { Between } 10,000 \\
\text { and } 20,000\end{array}$} & \multirow{2}{*}{$\begin{array}{l}\text { Between } 20,000 \\
\text { and } 50,000\end{array}$} & \multirow{2}{*}{$\begin{array}{l}\text { Between } 50,000 \\
\text { and } 100,000\end{array}$} & \multirow{2}{*}{$\begin{array}{c}\text { More Than } \\
100,000\end{array}$} \\
\hline Variable & & & & & \\
\hline Unit price of the tariff $\left(\mathrm{EUR} / \mathrm{m}^{3}\right)$ & 1.78 & 1.68 & 1.44 & 1.45 & 1.64 \\
\hline Unit price of sanitation $\left(\mathrm{EUR} / \mathrm{m}^{3}\right)$ & 1.03 & 1.03 & 0.82 & 0.88 & 0.85 \\
\hline Total unit price $\left(\mathrm{EUR} / \mathrm{m}^{3}\right)$ & 2.80 & 2.71 & 2.26 & 2.33 & 2.49 \\
\hline Weight of the standard invoice on income (\%) & 0.97 & 0.96 & 1.02 & 0.84 & 0.88 \\
\hline Weight of sanitation on income $(\%)$ & 0.53 & 0.53 & 0.55 & 0.47 & 0.44 \\
\hline Total weight on income $(\%)$ & 1.50 & 1.49 & 1.57 & 1.31 & 1.32 \\
\hline Household consumption ( $\mathrm{m}^{3} /$ year) & 104.70 & 109.14 & 117.45 & 118.93 & 109.27 \\
\hline Consumption per person ( $\mathrm{m}^{3} /$ year) & 50.62 & 51.71 & 59.44 & 55.02 & 54.84 \\
\hline Household members & 2.49 & 2.52 & 2.41 & 2.60 & 2.35 \\
\hline Household income (EUR/year) & $25,409.04$ & $23,006.56$ & $21,697.31$ & $26,787.04$ & $22,371.14$ \\
\hline Household income per person (EUR/year) & $11,671.59$ & $10,773.02$ & $10,490.80$ & $11,369.70$ & $10,677.71$ \\
\hline
\end{tabular}

Source: own elaboration based on INE data.

\section{Discussion}

The results obtained show some aspects of interest that are very important for the efficient treatment and reuse of wastewater. We have been able to observe how the energy consumption of the wastewater treatment plants in the Region of Valencia is very high, mainly due to the large number of small plants. However, it has also been observed that plants in the southern part of the region have a higher energy consumption than those in the north, but in return, they have higher disposal yields, so the quality of the outgoing water is better. This has a huge effect on the economic cost of this activity, as the energy cost is its main economic cost [10]. For this reason, it is convenient to analyse the source of income of this activity, which has shown us that there is a large difference between the structure of the sanitation tax and the tariffs applied to water supply. In this way, we find that the sanitation charge represents a small part of the total payments for water services or sanitation, which means that it is a very small part of household budgets. In this sense, and given the results obtained on the economic situation of households in the Region of Valencia, it would be worth considering making changes to the sanitation charge.

However, while the changes are appropriate, we must take into account the current design of the revenue source and how it relates to the current economic situation in the region. This is a fundamental aspect, as the revenue structure of water services is key to the efficient management of water resources [32,33]. In this sense, we can find different types of tariffs, among which linear tariffs and increasing tariffs stand out [34,35]. For this reason, the analysis about the structure of water tariffs and the aspects to be taken into account in wastewater treatment payments is of value beyond the study area. In the case of the Valencia Region, the tariff is linear, but the unit amount paid depends on the size of the municipality. Thus, the sanitation fee is lower in smaller municipalities, where the energy and economic cost of the activity is higher and the household income per person is higher than elsewhere. This is one of the aspects to be taken into account, as the energy cost is one of the most important in this activity. However, these smaller municipalities face a higher price for water supply than the rest. In other words, the situation is very complex, as the tariff for water supply and sanitation services is set at the local level, while the sanitation fee is the same for the whole region. Therefore, this difference implies that both types of payment are set independently and may have an unequal impact on households depending on the location. This is of great relevance, as the regional government seeks to ensure that public prices affect households in a balanced way. Unfortunately, in the absence of control over local prices, the regional price, which was subsequently established, is conditioned by them as long as it remains the objective of not overburdening household budgets. Given this situation, a simple increase in the charge can have important consequences on this objective and on the financing of the activity. It should not be forgotten that the cost to the household of the sanitation charge is actually quite small, and its increase could be difficult for users to perceive. In this respect, the importance of public acceptance of the activity should not be forgotten, as users' willingness to pay will be reduced if they do 
not correctly perceive the benefits obtained [36,37]. In any case, the results obtained for payment for supply and for sanitation services have shown us the large differences that can arise when water design revenues are designed at different territorial scales. In this respect, the balance between the two types of payment can vary greatly between regions. This is not a major problem as long as payments are not particularly high or there is no need for additional funding. However, it is a problem to be solved when tariff imbalances lead to problems of equity or financing of the service.

Given the lack of control over local payments, a sanitation tax capable of efficiently financing the activity of wastewater treatment and reuse is essential. In fact, it is not only a necessity of the Region of Valencia, but improvements must be introduced throughout Spain in order to adapt the activity to European regulations and achieve cost recovery [38]. In this sense, it is very convenient to assess whether the structure of this type of payment, which simply includes the size of the municipality, is the most appropriate. As discussed above, this simple structure is easy to manage, but it is not suitable for efficient revenue collection. This simple structure does not allow taking into account some aspects that have been shown to be relevant in determining the functioning of the activity. On the one hand, we should appreciate the fact that the tariff is linear, as it does not provide any disincentive to the water consumer. We should not forget that this price, in the eyes of the consumer, is part of the water invoice and reacts to it in conjunction with the water supply tariff. Thus, the ability of water pricing to stimulate efficient resource consumption is being underutilised. Linear tariffs, although not as common today as increasing block tariffs, still have a significant presence worldwide, and this type of analysis becomes relevant to study their modifications [34]. On the other hand, the wastewater treatment activity has some particularities that need to be considered. Firstly, the presence of pollutants in the water significantly conditions the operation of a treatment plant, so that a tariff that does not include this issue would be neglecting an important aspect of a treatment plant's performance [39]. Secondly, the situation is similar with respect to the energy cost, which has a significant environmental and financial cost and depends to a large extent on the efficiency of the treatment plant but has no influence on the tariff. These two aspects are an important part of a tariff that efficiently finances wastewater treatment. However, global tariffs do not include these relevant aspects, but their use is similar to those for water supply and does not take into account the particularities of this water service [34,39]. Thus, the analysis of the situation in the study region has allowed us to assess both the tariff structure and the aspects that should be included in it, which are universal issues that can be used elsewhere. The example of the Region of Valencia is a clear illustration of the impact of these issues on the operation of the plants and, therefore, of their financial costs and the need for appropriate tariffs. The situation in this region has shown us how the tariff must be adapted to specific situations in order to function efficiently. Otherwise, within that region, we would be faced with economic inefficiency and inequality of payments, which would be added to the already existing regional differences in Spain and Europe [40-43].

The current Valencian tax has an unequal impact on different households and does not generate sufficient revenue to address the energy consumption problems of wastewater treatment plants, especially the large consumption of smaller plants and the high greenhouse gas emissions associated with larger plants. Therefore, one alternative could be to modify the structure of the sanitation charge. The positive side of this possibility is that the different local tariffs have already worked on these issues, although in most cases the structure of these tariffs is reduced to introducing consumption brackets with increasing prices. This could be an alternative for the sanitation charge so as to discourage excessive consumption, which, apart from being an irresponsible act in environmental terms, leads to increases in the amount of wastewater to be treated in the purification facilities, with a corresponding increase in the size of the plants [15]. Thus, such consumption represents an unnecessary extraction of water resources and leads to an increase in the economic and environmental costs of wastewater treatment plants. A progressive sanitation charge, which would be coupled with similar tariffs, would address this issue. However, in any 
case, it would be interesting to have updated and accurate information on the economic and energy costs of each plant, as well as the population they serve, in order to be able to design the income from this activity in an efficient way.

Therefore, the current structure of the sanitation charge is adequate to achieve a certain level of revenue, but it is not adequate to finance the full (economic and environmental) costs of the activity, nor to have an equitable impact on the different users of the service. This is the reason for this analysis, which has allowed us to observe how the particularities of wastewater treatment require specific tariffs to obtain revenue in an efficient manner. Thus, aspects such as the pollution present in the wastewater and the energy cost of the installation should be assessed. Otherwise, the tariffs would not adequately convey the message they are intended to convey. In the same way that the water supply tariff seeks to inform about the financial cost of the service and the scarcity of the resource, the wastewater treatment tariff must convey the message of the high financial and environmental cost of the activity and the importance of minimising discharge pollution. In any case, it is very important to analyse the specific situation in a region before making tariff changes. Payments for water services should not be an excessive item in household budgets, but the financing of these services should be ensured in an efficient way. This issue, while relevant, is highly case-dependent, as the socio-economic situation may vary from case to case. At present, this is not only a problem of the Region of Valencia, but there is still a large worldwide presence of linear tariffs, but above all, the current wastewater treatment tariffs do not include the aspects discussed in this article. However, it should be noted that the inclusion of aspects related to the operation of the activity would imply a significant management cost, so this is an aspect that needs to be studied in depth.

\section{Conclusions}

The aim of this work was to analyse the current situation of the energy cost, with its respective economic cost, of the wastewater treatment and reuse activity in the Region of Valencia, as well as to determine the adequacy of the current sanitation tax used as a financing tool. The result is valuable information on what aspects should be taken into account when designing such a tariff. Thus, it has been found that, while the size of the installation is a key determinant of the energy and economic cost of the treatments, there are other aspects that must be taken into account. The possibility to geographically locate the available wastewater treatment plants has shown us that in the southern region, a higher energy cost is incurred in order to achieve a higher quality of the resulting water. The situation in the north is quite different, as the energy cost of the activity is lower, but it can also be observed that the outgoing water from the plants in that part of the analysis region has a lower quality.

Therefore, the size of the plant is a key aspect to consider when designing the tariff, but no geographical discrimination can be included in the form of financing. In any case, the particularities of this activity require a financing instrument that addresses the specific situation. In this sense, the current charge only takes into account the size of the municipality when setting a price. This may make some sense, but in practice it does not fit the situation we live in, where the environmental cost of wastewater treatment is unnecessarily high due to the lack of energy efficiency. For this reason, it would be interesting to obtain new revenues, for which it is necessary to look at the situation of households, which are the ones that provide the main financing. In doing so, we find that there is an imbalance in the payments for water services, as households in small municipalities suffer a higher price for water supply but enjoy a lower sanitation fee. In total, these households have a relatively high cost for the sum of water supply and sanitation services. In other words, while they contribute less funding to wastewater treatment, they pay more for local services. This shows a significant imbalance that is not controllable by the regional government, as with the exception of the sanitation tax, because prices are determined at a local level. However, we can highlight the fact that there are significantly higher payments on the one hand and relatively lower payments on 
the other hand. In this way, it would be interesting to evaluate the structural modification of the sanitation tax, as well as to improve communications between the different public administrations. In particular, it could be considered that the sanitation charge should include some component of the water supply tariffs, which try to adapt more to the situation. In this way, it could also be interesting to include consumption brackets in the charge, as excessive consumption implies greater wastewater purification, with its respective economic and environmental costs.

The issues addressed in this article are not unique to the Region of Valencia, but the information presented allows useful conclusions to be drawn for other regions. It has become clear how large differences can exist between regions in terms of payments for water services, which directly affects the equity of the tariff, which is one of the objectives of any tariff. Of course, obtaining the necessary revenues for the development of water services is the main objective of the diverse tariffs, but this must be done in a fair and balanced way, without overly affecting household finances and respecting as much as possible the principle that the polluter pays. In any case, while respecting these issues, the revenues of each water utility must take into account the particularities of each of them. Thus, when we talk about wastewater treatment, we find a series of aspects that, if not included in the tariff that finances the service, limit its efficiency. Thus, aspects such as the presence of pollutants in the water or the high energy cost of this activity are key determinants of the financial cost of wastewater treatment and should be part of the corresponding tariff. However, it should be noted that the size of the facilities is a particularly important issue, so it should not be ignored either. Therefore, there are several key aspects in the development of this activity that we need to consider when obtaining the revenues. This occurs, moreover, in a context where tariffs tend to have simple structures to facilitate their management. For this reason, the way to include these aspects in the wastewater treatment tariff must be administratively feasible.

This work opens an interesting line of research, because, although it has revealed the possibility of introducing modifications to the main financing tool for wastewater treatment, it does not have the necessary information to carry out a more in-depth analysis. The main limitations in terms of the information available are the availability of annual data, which prevents the seasonal aspect of water consumption from being considered, as well as the scarce information on the financial cost of the wastewater treatment plants. Therefore, it would be possible to continue developing this possibility with the aim of improving the management of an activity whose efficiency is so important.

Supplementary Materials: The following are available online at https:/ / www.mdpi.com/article/10 $.3390 /$ su13115874/s1.

Author Contributions: M.G.-L. is the main author of this research with the supervision of B.M. and J.M. In particular, B.M. contributed with data analysis, while J.M. contributed to data collection and to structuring the article. All authors have read and agreed to the published version of the manuscript.

Funding: This research was financed by the Office of the Vice President of Research and Knowledge Transfer of the University of Alicante, Spain (Marcos García-López has a scholarship for The Training of University Teachers from the University of Alicante, UAFPU2019-16).

Institutional Review Board Statement: Not applicable.

Informed Consent Statement: Not applicable.

Data Availability Statement: The Household Budget Survey is available on the Spanish National Statistics Institute website, which can be consulted in English, but the design of the survey is only available in Spanish. The data about wastewater treatment and sanitation tax come from the EPSAR website, while the tariff of Alicante can be consulted on the webpage of Aguas de Alicante. Lastly, the data about costs recovery come from the websites of both hydrographic confederations mentioned in the text (available in references).

Acknowledgments: This work was supported by the Office of the Vice President of Research and Knowledge Transfer of the University of Alicante, Spain, the University Institute of Water and 
Environmental Sciences of the University of Alicante, the Water Chair of the University of AlicanteAlicante Provincial Council and the Hábitat5U network of excellence. We would also like to thank the editor and reviewers involved in the publication process for their valuable comments to improve the article.

Conflicts of Interest: The authors do not have financial or personal interests that could have influenced the paper.

\section{References}

1. Navarro, T. Water reuse and desalination in Spain-challenges and opportunities. J. Water Reuse Desalination 2018, 8, 153-168. [CrossRef]

2. Barella-Ortiz, A.; Quintana-Seguí, P. Evaluation of drought representation and propagation in regional climate model simulations across Spain. Hydrol. Earth Syst. Sci. 2019, 23, 5111-5131. [CrossRef]

3. Spinoni, J.; Barbosa, P.; Bucchignani, E.; Cassano, J.; Cavazos, T.; Christensen, J.H.; Christensen, O.B.; Coppola, E.; Evans, J.; Geyer, B.; et al. Future Global Meteorological Drought Hot Spots: A Study Based on CORDEX Data. J. Clim. 2020, 33, 3635-3661. [CrossRef]

4. EPSAR. “Memoria de Gestión”. Ejercicio 2019. Entidad Pública de Saneamiento de Aguas Residuales de la Comunidad Valenciana, Valencia. 2020. Available online: https:/ / www.epsar.gva.es/sites/default/files/2020-07/INFORME-DE-GESTION_2019.pdf (accessed on 28 March 2021).

5. EU. Directive 2000/60/EC of the European Parliament and of the Council Establishing a Framework for the Community Action in the Field of Water Policy 2000. Available online: https:/ / eur-lex.europa.eu/legal-content/EN/TXT/?uri=CELEX:32000L0060 (accessed on 28 March 2021).

6. EEC. Directive 91/271/EEC of the Council Directive of 21 May 1991 Concerning Urban Waste-Water Treatment 1991. Available online: https: / / eur-lex.europa.eu/legal-content/ES/TXT/?uri=LEGISSUM\%3Al28008 (accessed on 28 March 2021).

7. Melgarejo, J. Efectos Ambientales y Económicos de la Reutilización del Agua en España. CLM Econ. 2009, 15, 245-270.

8. Hernández-Sancho, F.; Molinos-Senante, M.; Sala-Garrido, R. Eficiencia energética, una medida para reducir los costes de operación en las estaciones depuradoras de aguas residuales. Tecnol. del agua 2011, 31, 46-54.

9. Albadalejo-Ruiz, A.; Martínez-Muro, J.L.; Santos-Asensi, J.M. Parametrización del consumo ener-gético en las depuradoras de aguas residuales urbanas de la Comunidad Valenciana. TecnoAqua Lucca Italy 2015. Available online: https:/ / www.tecnoaqua.es/media/uploads/noticias/documentos/articulo-tecnico-parametrizacion-consumo-energeticodepuradoras-agua-residuales-urbanas-comunidad-valenciana-tecnoaqua-es.pdf (accessed on 5 May 2021).

10. Albadalejo-Ruiz, A.; Trapote, A. Influencia de las Tarifas Eléctricas en los Costes de Operación y Mantenimiento de las Depuradoras de Aguas Residuales. TecnoAqua 2013, 3, 48-54.

11. McDonald, R.I.; Weber, K.F.; Padowski, J.; Boucher, T.; Shemie, D. Estimating watershed degradation over the last century and its impact on water-treatment costs for the world's large cities. Proc. Natl. Acad. Sci. USA 2016, 113, 9117-9122. [CrossRef]

12. Melgarejo, J.; Prats, D.; Molina, A.; Trapote, A. A case study of urban wastewater reclamation in Spain: Comparison of water quality produced by using alternative processes and related costs. J. Water Reuse Desalination 2016, 6, 72-81. [CrossRef]

13. Rowan, P.P.; Jenkins, K.L.; Howells, D.H. Estimating sewage treatment plant operation and maintenance costs. J. (Water Pollut. Control Fed.) 1961, 33, 111-121.

14. Marzouk, M.; Elkadi, M. Estimating water treatment plants costs using factor analysis and artificial neural networks. J. Clean. Prod. 2016, 112, 4540-4549. [CrossRef]

15. Renzetti, S. Municipal Water Supply and Sewage Treatment: Costs, Prices, and Distortions. Can. J. Econ. 1999, 32, 688. [CrossRef]

16. Tardieu, H.; Préfol, B. Full cost or "sustainability cost" pricing in irrigated agriculture. Charging for water can be effective, but is it sufficient? Irrig. Drain. 2002, 51, 97-107. [CrossRef]

17. Zetland, D.; Gasson, C. A global survey of urban water tariffs: Are they sustainable, efficient and fair? Int. J. Water Resour. Dev. 2013, 29, 327-342. [CrossRef]

18. Rogers, P. Water is an economic good: How to use prices to promote equity, efficiency, and sustainability. Hydrol. Res. 2002, 4, 1-17. [CrossRef]

19. Nauges, C. Is all domestic water consumption sensitive to price control? Appl. Econ. 2004, 36, 1697-1703. [CrossRef]

20. Zikos, D. Urban water dilemmas under the multi-dimensional prism of sustainability. Trans. Bus. Econ. 2008, 8, 413-422.

21. Hughes, N.; Hafi, A.; Goesch, T. Urban water management: Optimal price and investment policy under climate variability. Aust. J. Agric. Resour. Econ. 2009, 53, 175-192. [CrossRef]

22. Renzetti, S. Evaluating the welfare effects of reforming municipal water prices. J. Environ. Econ. Manag. 1992, 22, 147-163. [CrossRef]

23. Arbués, F.; Villanúa, I.; Barberán, R. Household size and residential water demand: An empirical approach. Aust. J. Agric. Resour. Econ. 2010, 54, 61-80. [CrossRef]

24. Dahan, M.; Nisan, U. Unintended consequences of increasing block tariffs pricing policy in urban water. Water Resour. Res. 2007, 43, 3. [CrossRef]

25. Rey, D.; Pérez-Blanco, C.D.; Escriva-Bou, A.; Girard, C.; Veldkamp, T.I.E. Role of economic instruments in water allocation reform: Lessons from Europe. Int. J. Water Resour. Dev. 2019, 35, 206-239. [CrossRef] 
26. Arbués, F.; Barberán, R.; Villanúa, I. Price impact on urban residential water demand: A dynamic panel data approach. Water Resour. Res. 2004, 40, 11. [CrossRef]

27. Confederación Hidrográfica del Júcar, “Memoria”. Plan Hidrológico de Cuenca 2015-2021. 2015. Available online: https:/ /www. chj.es/es-es/medioambiente/planificacionhidrologica/Paginas/PHC-2015-2021-Plan-Hidrologico-cuenca.aspx (accessed on 29 March 2021).

28. Confederación Hidrográfica del Júcar, “Documentos iniciales. Memoria”. Plan Hidrológico de la Demarcación Hidrográfica del Júcar. Revisión de Tercer Ciclo (2021-2027). 2019. Available online: https://www.chj.es/es-es/medioambiente/ planificacionhidrologica/Paginas/PHC-2021-2027-Indice.aspx (accessed on 29 March 2021).

29. Confederación Hidrográfica del Segura, "Memoria”. Plan Hidrológico de la Demarcación Hi-Drográfica del Segura $2015-2021$. 2015. Available online: https:/ / www.chsegura.es/es/cuenca/planificacion/planificacion-2015-2021/plan-hidrologico-2015-2 021/ (accessed on 29 March 2021).

30. Confederación Hidrográfica del Segura, “Documentos iniciales. Memoria”. Plan Hidrológico de la Demarcación Hidrográfica del Júcar. Revisión de Tercer Ciclo (2021-2027). 2020. Available online: https:/ /www.chsegura.es/es/cuenca/planificacion/ planificacion-2021-2027/el-proceso-de-elaboracion/ (accessed on 29 March 2021).

31. Aguas de Alicante, “Modificación de las Tarifas de Abastecimiento de Agua, Conservación de Con-Tadores, Contratación y Reposición en Alicante". Boletín Oficial de la Provincia de Alicante. 2021. Available online: https:/ / www.aguasdealicante.es / documents / 231378/2242840/BOP-TARIFAS-ALICANTE-24-03-2021.pdf/e5273503-86e7-80b8-d165-1c88068bb1cd (accessed on 29 March 2021).

32. Marques, R.C.; Miranda, J. Sustainable tariffs for water and wastewater services. Util. Policy 2020, 64, 101054. [CrossRef]

33. Molinos-Senante, M.; Hernandez-Sancho, F.; Sala-Garrido, R. Tariffs and Cost Recovery in Water Reuse. Water Resour. Manag. 2012, 27, 1797-1808. [CrossRef]

34. Damkjaer, S. Drivers of change in urban water and wastewater tariffs. H2Open J. 2020, 3, 355-372. [CrossRef]

35. Nauges, C.; Whittington, D.; El-Alfy, M. A simulation model for understanding the consequences of alternative water and wastewater tariff structures: A case study of fayoum, Egypt. In Freshwater Governance for the 21st Century; Springer Science and Business Media: Berlin, Germany, 2015; pp. 359-381.

36. Smith, H.M.; Walker, G. The Political Economy of Wastewater in Europe. In Water Science, Policy, and Management: A Global Challenge, 1st ed.; Dadson, S.J., Garrick, D.E., Eds.; John Wiley \& Sons: Hoboken, NJ, USA, 2019; Volume 12, pp. 215-232. [CrossRef]

37. Simachaya, W. Wastewater tariffs in Thailand. Ocean Coast. Manag. 2009, 52, 378-382. [CrossRef]

38. Jodar-Abellan, A.; López-Ortiz, M.I.; Melgarejo-Moreno, J. Wastewater Treatment and Water Reuse in Spain. Current Situation and Perspectives. Water 2019, 11, 1551. [CrossRef]

39. Ruiz-Rosa, I.; García-Rodríguez, F.J.; Antonova, N. Developing a methodology to recover the cost of wastewater reuse: A proposal based on the polluter pays principle. Util. Policy 2020, 65, 101067. [CrossRef]

40. Valero, L.G.; Pajares, E.M.; Sánchez, I.M.R.; Pérez, J.A.S. Analysis of Environmental Taxes to Finance Wastewater Treatment in Spain: An Opportunity for Regeneration? Water 2018, 10, 226. [CrossRef]

41. Pajares, E.M.; Valero, L.G.; Sánchez, I.M.R. Cost of Urban Wastewater Treatment and Ecotaxes: Evidence from Municipalities in Southern Europe. Water 2019, 11, 423. [CrossRef]

42. Valero, L.G.; Pajares, E.M.; Sánchez, I.M.R. The Tax Burden on Wastewater and the Protection of Water Ecosystems in EU Countries. Sustainability 2018, 10, 212. [CrossRef]

43. García-Valiñas, M.; Arbués, F. Wastewater Tariffs in Spain. In Oxford Research Encyclopedia of Global Public Health; Oxford University Press: Oxford, UK, 2021. 